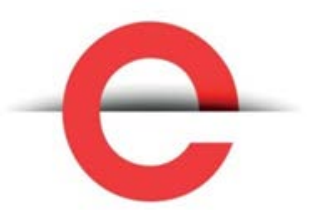

U T S

e PRE S S

Cosmopolitan

Civil Societies: an

Interdisciplinary

Journal

Vol. 9, No. 1

2017

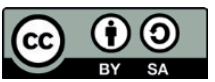

(C) 2017 Steve Kwok-Leung

Chan. This is an Open

Access article distributed

under the terms of the

Creative Commons

Attribution 4.0 Unported

(CC BY 4.0) License (https://

creativecommons.org/

licenses/by/4.0/), allowing

third parties to copy and

redistribute the material in

any medium or format and to

remix, transform, and build

upon the material for any

purpose, even commercially,

provided the original work is

properly cited and states its

license.

Citation: Chan, S. 2017.

Prostrating Walk in the

Campaign against Sino-Hong

Kong Express Railway:

Collective Identity of Native

Social Movement. Cosmopolitan

Civil Societies: an

Interdisciplinary Journal. 9(1),

20-41.

http://dx.doi.org/10.5130/ccs.v9i

$\underline{1.4986}$

ISSN 1837-5391|Published by UTS ePRESS|https://epress. lib.uts.edu.au/journals/index. php/mcs
REFEREED PAPER

\section{Prostrating Walk in the Campaign against Sino-Hong Kong Express Railway: Collective Identity of Native Social Movement}

\author{
Steve Kwok-Leung Chan \\ SIM University, Singapore
}

Corresponding author: Steve Kwok-Leung Chan, School of Human

Development and Social Services, SIM University, 461 Clementi Road, Singapore

599491. Corresponding author: sklchan@gmail.com

DOI: http://dx.doi.org/10.5130/ccs.v9i1.4986

\begin{abstract}
Occupation, blockage and storming are not rare in social movements a decade after China resumed sovereignty in Hong Kong. The organizers and participants usually involve locally born young people. Some of them are secondary school students in their teens. They are known as the fourth generation or post-1980s born Hongkongers. The paper examines the cultural context of social movements involving these youth activists. It focusses on the campaign against the Sino-Hong Kong Express Railway development project. The project called for the demolition of the Tsoi Yuen Village, a small rural village located on its designated route. Since then, the role of the younger generation in social movements has been recognized more broadly. Social media are widely employed in all stages of the movements with citizen journalists actively involved. The impressive ‘prostrating walk' imitating Tibetan pilgrims has become a symbol of these youth activists. It has kept appearing in other campaigns including Occupy Central in Hong Kong in 2014. This paper argues that the rise of nativism, advancement in ICT technology and the shift towards new social movements contribute to the dominant role of youth in recent social movements of Hong Kong. Collective identity of Hongkonger in response to the top-down assimilation by China strengthens the movement.
\end{abstract}

\section{Keywords}

Prostrating Walk, New Social Movement, Nativism, Youth Activism, Hong Kong, Sino-Hong Kong Express Railway

DECLARATION OF CONFLICTING INTEREST The author(s) declared no potential conflicts of interest with respect to the research, authorship, and/or publication of this article. FUNDING The author(s) received no financial support for the research, authorship, and/or publication of this article. 


\section{Introduction}

The rise of direct actions by youth activists in the form of transgressive movements gradually emerged in 2006, a decade after China resumed sovereignty in Hong Kong. The campaign organizers and participants usually involve locally born young people. Some of them are secondary school students in their teens. They are known as the fourth generation or post1980s born Hongkongers. The paper examines the cultural context of social movements involving these youth activists. It mainly studies the campaign against the Sino-Hong Kong Express Railway development project in 2009 and 2010. This single railway project needs to be understood in the context of the top-down assimilation by Mainland China of Hong Kong. Economic fusion, tightening social control and prohibiting further democratization play together with this cultural pattern.

This paper attempts to introduce the discourse of collective identity of youth activism in connection to the rise of nativism. The framework of the new social movement was also adopted in collaboration with the notion of collective identity. In particular, the ethnography of post-1980s 'prostrating walks' imitating the Tibetan Buddhists and Koreans during the Korean peasants' anti-WTO protest in Hong Kong is examined. 'Prostrating walks' appear in other campaigns including Occupy Central in 2014. This study argues that the collective identity discourse on the rise of nativism, advancement in ICT technology and shifting towards new social movements contribute to the youth activism in post-colonial Hong Kong.

\section{New Social Movement}

At a glance, social movements are collective actions, initiated and organized by social groups or organizations. They address a single issue or wider social and political institutions. In some instances, social movements are not a short-term campaign but last for a period of time or even one or more generations. Some social movements aim to achieve social and institutional change. Diani (2006) defines social movements as:

networks of informal interactions between a plurality of individuals, groups and/or organizations, engaged in political or cultural conflicts, on the basis of shared collective identities.

MacAdam (1997) emphasizes social movements happening 'outside institutional channels'. Usually, a series of contentious performances, displays and campaigns are used by groups and organizations to express their collective views (Tilly, 2004).

The idea of new social movements emerged in the 1960s and 1970s in response to economic structural changes in Western countries. The class-based, specific group interest oriented social movements were gradually not able to cope with new issues in the postindustrial world. The motivations of people taking part are not restricted to materialistic and self-interest goals (Calhorn 1993; Melucci 1985; Offe 1985, Rose 1997; Touraine 1985). New movements in developed countries cover themes of feminism, civil rights, environmental protection, peace and anti-nuclear and the like. Sometimes they are known as new social movements. They are usually centred on issues that go beyond social class. Offe (1985) regards it as a shift from 'class-basis' to 'issue-basis' movements. 
The expansion of the middle class also broadens the range of concern. More and more professionals and middle class have become involved in new social movements, namely peace movements, environmental movements, women's movements, and civil movements. For example, Greenpeace, the well-known environmental group favouring direct action, consists of members with higher incomes and college educations than the average US citizen. 'Leadership of these movements is drawn even more disproportionately from the professional middle class' (Rose 1997, p.464). However, Offe (1985) points out the heterogeneity of new social movement membership. There are more middle-class individuals taking part, but the membership is more diverse. Also, many of the supporters are new middle class coming from the personal-service sector, with high educational status and economic security. Most importantly, there is greater participation from the new middle class in these movements, but 'the demands (and thus beneficiaries of such demands) are highly class-unspecific, dispersed ... universalistic in nature ...' (Offe 1985, p.833).

Furthermore, old and new social movements can be distinguished in terms of their orientation, goals and values, participants as stated above, but also the mode of action. The organization of new social movements is more 'informal, ad hoc, discontinuous, contextsensitive, and egalitarian' (Offe 1985, pp.829-830). This flexibility is to cope with the complexity of post-industrial society that brings about the rise of new forms of social movement. This shift of social movements away from highly differentiated industrial society is coherent with Offe's (1985) 'de-differentiation' of the internal mode in new social movements.

[N]ew social movements do not rely[...] on the organizational principle of differentiation, whether in the horizontal (insider vs. outsider) or in the vertical dimension (leaders vs. rank and file members)[...] strong reliance upon dedifferentiation[...] the fusion of public and private roles, instrumental and expressive behavior, community and organization, and in particular a poor and at best transient demarcation between the roles of members and formal leaders (Offe 1985, pp.829830).

In the Hong Kong context, Lui and Chiu (2000) mentioned briefly signs of new social movements in the 1980s and 1990s. There existed small-scale environmental movements and women's campaigns. But the environmental groups were institutionalized, under government and corporate sponsorship to offer mainly education programs. While the grassroots women's actions did address wider political and social causes (Lee 2000), in the last two decades, before the 1997 handover of Hong Kong, there were more protest activities and their scale grew gradually. However, lack of trust and little cooperation was the norm between political parties and civil society organizations. Such ad hoc alliance is effective but seldom able to accumulate enough resources in order to bring institutional change (Ma 2009).

After the outbreak of a new strain of infectious disease in Hong Kong in 2003, the panic created new societal values for Hongkongers, not based on materialism ${ }^{1}$. More emphasis was given to environmental and health issues. The shift of values led to the rise of post-materialist youth activism which challenged the government's economy first

\footnotetext{
${ }^{1}$ An outbreak of severe acute respiratory syndrome (SARS) in 2003 in Hong Kong led to a number of deaths. It then spread to other countries in the region, thereby creating panic.
} 
development practice and procedural justice in public policy processes (Yew \& Kwong 2014). Cheung (2014, pp.429-430) regards the Tsoi Yuen Village resistance as a new kind of social movement because it was able to 'exert huge political pressure on the government'. He also employed the term 'new social movements' in describing the transgressive mode of action, using 'confrontational, uncompromising and unorthodox strategies' beyond institutional channels (Or \& Lau 2014). The actions involve innovative collective action performed by newly identified political actors. Transgressive actions are usually regarded as rebellion and radical, in some instances (Moyer et al. 2001; Cheung 2014; Or \& Lau 2014). Sometimes protest involved minor scuffles as well as direct body contacts between petitioners and the police, though scuffles never happened (Cheung 2014).

\section{Cultural Politics and Collective Identity}

A split in society is usually the origin of social movements though Resource Mobilization theorists de-emphasize the factor of grievance in triggering contentions. Touraine (1985) distinguishes different types of social conflicts, namely:
I. The competitive pursuit of collective interests;
II. Reconstruction of a social, cultural or political identity;
III. A political force which aims at changing the rules of the game;
IV. The defence of a status or privileges;
V. The social control of main cultural patterns; and
VI. Creation of a new order.

Among them, cultural identity (type II) and cultural pattern (type V) are not restricted to new social movement theories, but also widely adopted in arguments of framing and postmodern politics of resistance. For example, the resistance of occupational groups during economic restructuring and ethnic groups defending their rights involve both political and economic goals. While the social control of the main cultural patterns implies the ruling classes imposing cultural values on the masses, the hierarchy here reflects the political relationship of the system. Further, this subordination may determine patterns of resource allocation and lifestyle. The resistance becomes a cultural struggle where activists 'translate their demands into a cultural code' (Touraine 1985).
Movements don't exist only in their cultural message; they are also social organizations, and they confront political systems when choose public mobilization... Collective action acts as symbolic multiplier... [It] challenges the operational logic of technocratic-military apparatuses and questions the bases of their power... It makes the power visible (Melucci 1985, p.813).

Does the cultural-turn depoliticize social movements? Early theories of new social movement claim that the main conflict in post-industrial society has shifted from the material to the cultural production of society. It is the conflict or historicity in the sphere of civil society, instead of class position in the structure and economic demands that triggers social movements. The struggle becomes focussed on the 'cultural means of social production' (Staricco, 2012). However, the shifting of the struggle from economic recourses and social 
class structure to identity politics involves the defense of civil society against the manipulation of cultural resources by the performance power. Also, social movements politicize the cultural field which previously comprised non-politicized areas of social life (Evers, 1985; Kauffman, 1990; 2012).

In some instances, cultural struggle involves collective identity building. Individuals negotiate with others, groups and the external environment to form their identity. This identity or identities gathers together like-minded people to form groups and act together for common ends. It is not a static process. Social identity theory suggests social identity is a sense of group membership, in which individuals perceive their own identity or which they accept as defined by other group members. The discovery or build-up of social identity involved categorization, identification and comparison processes (Tajfel \& Turner 1979).

Collective identity is found in the shared feelings, values and norms of a group which contribute to group cohesion. In negotiating with the wider society beyond the group, collective identity can be both defensive and offensive. In a conflict situation, where identity and its materialistic (resources, wealth and income) or non-materialistic derivatives (folkways, values and institutions) are under threat, the group will take action to respond. Polletta and Jasper (2001, p.285) define collective identity as 'an individual's cognitive, moral and emotional connection with a broader community, category, practice, or institution', which comprises but is not limited to cultural material, including lifestyles, religions, symbols, languages, and the like.

Popular schools in social movements have a diverse focus. Collective behaviourists explain the process, the resource mobilization school relies on individuals' rational calculation, and political process theorists are concerned with political climates and opportunities. Collective identity has also been employed in explaining how movements emerge, participants' motivation, strategic choices and the cultural effects of social movements. Collective identity in social movements predicts organization forms and decision-making modes, which are coherent with new social theories. Collective discussion helps to build consensus in the less institutionalized environment, while 'shared leadership' in the 'horizontal organization’ facilitates participation (Fominaya 2010, p.396).

Identity construction through political activism can be proactive and reactive. It is a reflexive process through which identity is produced and reproduced while the individual takes part in direct action. A reducing reflexivity would result in the identity of activists being shaped largely by their environment (or 'society'). An expanding reflexivity would arise from the activists shaping their own identity, norms, and images, according to their will and own design which subsequently gets the recognition of the predominant group and the society at large. In reality, identity construction is a bidirectional and ongoing process with the activists negotiating with people, organizations and social structure back and forth. As such, involvement is crucial. The motive for participation can be altruistic impulse or response to grievances. But in the early days, activists were believed to be psyches seeking 'displacement of dissatisfaction experienced in other spheres of life' (Lasswell, 1960, cited in Teske, 1997). Later, the resource mobilization approach suggested a quasi-quantitative calculation of costs and benefits and emphasized agency and the promotion effort of professional organizers or 'political entrepreneurs' (Teske, 1997, p.19). But identity construction is about 'certain 
qualities instantiated in [the activists'] [...] actions and lives. As such, the motivation to act is to identify that 'one is certain kind of person' (Teske, 1997, p.121).

As to the construction of collective identity, one way is to manipulate signs and symbols by assigning meanings to them 'in order to fabricate the world and to subsume it to the signs with which we express (or do not express) it' (Melucci, 1996, p.131). These symbols, icons and images are signifiers transmitting emotions. Emotional packages consisting of affection, excitement, pride, joys and/or sorrows help to motivate participants as well as win public sympathy (Eyerman 2005; Goodwin and Jasper, 2006). Emotions underpin collective identities; which can be shared among activists and promote solidarity (Hurd, 2014). They sometimes speak more loudly than words and impress bystanders in the society at large. A more systemic way to spread the message among activists and to the public is through rituals. For example, Routledge's (1997) study on the campaign against the construction of a new motorway through the Pollock Park in Scotland finds that besides conventional ways of marching and occupation, a series of symbolic challenges were used. For example, the activists declared the construction site they occupied as 'free state' and issued 'passports' for the 'state'. A tree house was built on the 'state's territory'. The message of challenges to the planning of space was spread through media with the assistance of cultural symbols and signifiers (Jones et al., 2004).

Rituals, a specific form of signifier, sometimes appear in social movements characterized by formalism, traditionalism, invariance, rule-governance, sacral symbolism and performance (Bell, 1997). They provide the action 'with narratives[...] [which] embodied collective remembering[...] [t]his moral-social identity implies both a shared past and a hopeful future' (Hurd, 2014). Furthermore, rituals in social movements affirm the identities and beliefs of participants. As the performance of these rituals involves the physical presence of activists and audience in public spaces, emotional energy can be created through face-to-face social interactions. 'Rituals synchronize the action and develop symbolic and moral representation' (Goodwin and Jasper, 2006).

The new social movement theory has its critics. Nash (2000) points out that new social movement theory downplays the importance of social movements mobilized on issues less than systematic transformation. Also, Touraine's analysis has focused too much 'on ideology in the framing of identity' (Taylor, 2010, p.109). Further, the proponents place too much emphasis on the social aspect and downplay the economic or political aspects. However, social issues originate in the existing social and power structure and many organizations involved in new social movements are, actually, existing formal organizations which provide fewer chances for members to participate.

Touraine presumes that social movements happen in societies reaching a certain stage of development. This Eurocentric approach limits the theory in explaining activism in developing and authoritarian states. For example, in authoritarian states, the social control limits the public space for civil society. In fact, in many developing countries, the regimes are oligarchies manipulated by a dictator, a single political party, a dominant group and their cronies. The struggle for public space, lifestyle, the environment and the like inevitably exerts challenges to the regime and vested interests. 


\section{The Rise of Nativism in Hong Kong}

Hong Kong is a former British colony, with the People's Republic of China resuming sovereignty in 1997. The city became a Special Administrative Region of China under a mini-constitution, known as the Basic Law of Hong Kong. According to the Basic Law, the Chief Executive (selected by an election college) has replaced the former British Governor as head of the government. The legislature is a semi-elected body with half of its members elected by functional constituencies. The guiding principle is 'One Country, Two Systems', with Hong Kong citizens governing the city under a high degree of autonomy.

It is worth mentioning the rise of nativism in the post-1997 era after China has resumed its sovereignty of Hong Kong. There is a growing number of residents in Hong Kong claiming that they are 'Hongkongers', rather than 'Chinese'2. The sense of native identity has become stronger and stronger to distinguish themselves from Mainland Chinese. (Figure 1)

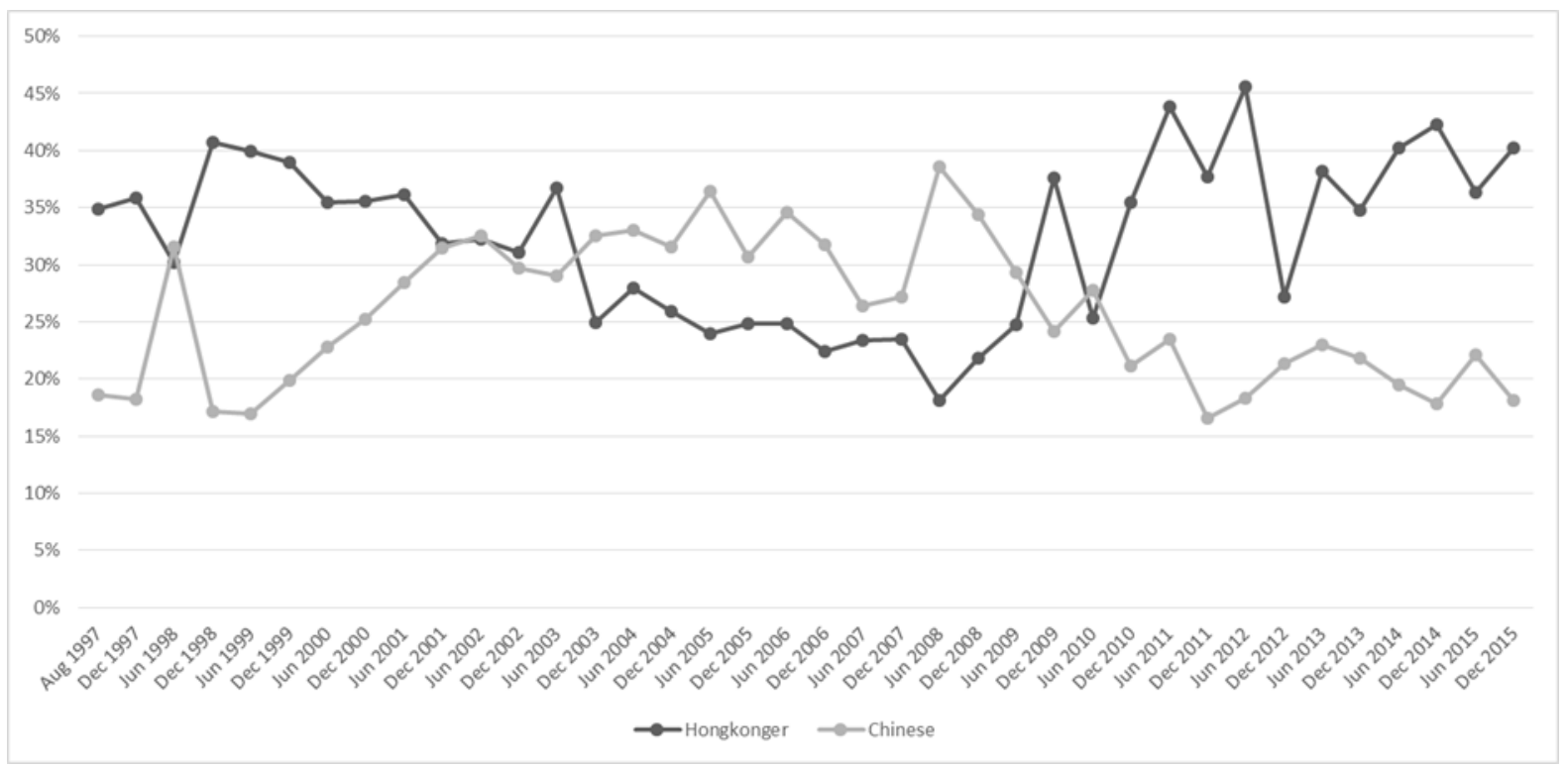

Figure 1. Hongkonger versus Chinese Identity

Source: Modified from Table: People’s Ethnic Identity Survey, Public Opinion Programme, University of Hong Kong (Public Opinion Programme, n.d.).

With reference to the chart above, the divide between Hongkongers and Chinese became wider after 2008 when the old pier of Star Ferry was demolished. The incident led to a confrontation between the government and post-1980s youth activists who campaigned for the conservation of this urban heritage structure. However, the Star Ferry Pier and its clock tower erected in 1958, by no means can be regarded as a historical building. Its only real significance was its pre-1997 cultural identity (Tsui 2007). The emergence of de-Sinofication sentiments summarizes the effects of the reaction to China's manipulation, incompetent

\footnotetext{
${ }^{2}$ According to the longitudinal studies of the Public Opinion Programme of the University of Hong Kong, 67 percent and 31 percent of the respondents identified themselves as 'Hongkongers' and 'Chinese' respectively. In the survey conducted in June 2014, both 'Hongkongers' and 'Chinese' had a broader sense, such that the former consists of a choice of either 'Hongkonger' or 'Hongkonger in China' and the latter either as 'Chinese' or 'Chinese in Hong Kong’. (Public Opinion Programme 2014)
} 
governance by the Hong Kong Government, cultural conflicts between local residents and mainlanders, economic downturn due to deindustrialization and the like. The consequence is a rapid rise of nativism.

The post-1980s youth activism was disconnected from their older generations who were apolitical and worked hard to earn a living in Hong Kong. The post-WWII, older generations were migrants from the mainland of China, who positioned themselves as 'transient citizens' of Hong Kong during the old days of this British colony. They had a 'refugee mentality' (Matthews, Ma \& Lui, 2007 p.38), in which Hong Kong was one of their stepping stones in the diaspora. For most of these newly arrivals from the mainland of China, with limited choices, they settled down temporarily in this British colony of Hong Kong, waiting for an alternative and just regarding it as 'a borrowed place on borrowed time... [which] could never be home' (Fowler, 2015). The next cohort is native born Hongkongers from the1960s and 1970s, who are referred to by my term 'hidden citizens'. They grew up in the transition period between a couple of contradicting political events ${ }^{3}$. It was not a social and political change in one direction of development but fluctuated up and down. On the one hand, this cohort was influenced by their parents to stay away from politics. On the other hand, they were confused by their life experience. Among them, some are the middle class who have emigrated to Western countries before the handover. They then sojourned back to Hong Kong as returning migrants entitled to dual citizenship (Marston and Mitchell, 2004). Another group became expatriates working in Mainland China or they are Small and Medium Enterprise business people trading with or relocating their production plants to the Pearl River Delta. The rest remained the silent majority in domestic politics, continuing their routines from dawn to dusk.

In contrast, the cohort born post-1980s comprises active citizens, without the same political culture as their previous generations. They are 'netizens' spending less time on gradually self-censored mainstream local news media. Rather, they are well-informed via the internet and connected by social media either through their tablets or smartphones. Spoon feeding by state influenced, traditional media in the post-colonial period did nothing to control their minds. All communication modes in their dictionary took two approaches. This nurtured their outspoken attitude, bottom-up approaches and participatory culture. Many of them witnessed, and some joined, the demonstration against the Treason Law on 1 July 2003. More than half a million people turned out to oppose the legislation imposed by China on Hong Kong. The incident also led to the stepping down of the Chief Executive of the city a year later. This generation has become aware of their citizenship rights and is cautious against various controls gradually imposed by China. To be a Hongkonger implies an active citizen role in local affairs. 'Local identity can only be created through the continuous recreating of Hong Kong society’ (Ma \& Liang, cited in Kaeding 2011, p.5).

It is now important to position this typology of citizenship in respect of migration and political culture changes. The early work of Almond and Verba's (1963) distinction of political culture into parochial, subject and participant societies provides some hints. People in each type of society have a different level of concern for their citizenship rights and level

\footnotetext{
${ }^{3}$ These events are namely the riot in 1967, economic reform adopted by communist China in 1978, Sino-British Joint Declaration on the Future of Hong Kong in 1984, the crackdown of the movement in Tiananmen Square in Beijing in 1989 and finally, the British handover of Hong Kong to China in 1997.
} 
of participation in politics ${ }^{4}$. As Hong Kong is an immigrant community ${ }^{5}$, it is worth taking the factor of migration into account in this model. Citizenship is more than a legal concept ${ }^{6}$. The possession of a citizen identity card does not necessary mean the entitlement of full citizenship rights. Citizenship formation and practice is an ongoing process in space over time (Marston and Mitchell, 2004). First-generation immigrants who were born in the sending country some may take the time to integrate into the receiving country, while other may even refuse to or be blocked from integrating. The study of Wiley et al., (2013) on firstgeneration Latino immigrants in the northeastern United States suggests that ethnic-based rejection has unique implications for identification and ethnic political engagement. Ethnic Chinese raised in British Hong Kong have nurtured a dual and transitional identity of liminal citizenship $^{7}$, which 'relate[s] to a transitional or initial stage of process[...] occup[ing] a position at, or on both sides of, a boundary or threshold' (Cheung, 2007, p. 87). During and soon after the British negotiated with China the handover of Hong Kong, some affluent middle-class Hongkongers emigrated to Britain, Canada and other English-speaking, developed countries so as to retain their way of life, and subsequently sojourned back to work in Hong Kong. They are 'transmigrants' holding dual citizenship who 'live bi-nationally, setting up homes and places of work in more than one nation-states[... which] confers identity within a national community without the necessary of residing or working in that community' (Marston and Mitchell, 2004, p.106). These different national identities, interests and connections contribute to differential civic engagement to local and political affairs in Hong Kong.

Finally, the concept of active citizenship is distinguished from legal and statist citizenship which is determined top-down solely by the authority. Citizenship is no longer taken for granted, but as something that needs to be perceived actively 'by individuals through participation in governance and sharing responsibility for the defence of citizenship rights' (Jones et al., 2004, p.142). It is grounded in civil society (Friedmann 2002), expanded in the public sphere (Rose 2000) and mobilized through social movements (Miraftab and Wills, 2005). This paper claims that native-born Hongkongers in the 1980s and beyond choose to engage actively in various social events and try to make some changes. The

\footnotetext{
${ }^{4}$ Parochial societies are those in which the majority people have little concern for their citizenship and the state. They do not care about politics and public affairs or generally 'neither the desire nor the ability to participate in politics'. Subject societies consist of people in some instant, who understand and passively observe politics, but remain less participative. People of participant societies are true citizens. They are aware of politics and eager to stand up for their rights. They have 'political competence and political efficacy'. (Almond and Verba 1963, p.79)

${ }^{5}$ More than half of the population of Hong Kong was internal migrants from the mainland of China during the post-WWII period until the end of the Touch-base Policy in 1980. The policy was adopted by the British Hong Kong Government in 1974, and it allowed immigrants from the mainland of China to claim Hong Kong citizenship once they reached the urban areas of the British colony of Hong Kong.

${ }^{6}$ The different in legal concept citizenship between Hong Kong and China also leads to confusion. Hong Kong follows the British legal practice of Jus soli, or the 'right of soil' which is the principle of birth-right citizenship. China citizenship is based on jus sanguinis or the 'right of blood', in which citizenship is acquired by inheritance, according to the blood origin.

${ }^{7}$ Skeiker (2010, p.13) suggests liminal citizens as those 'who live in a host community for a significant period of time without becoming a legal citizen of that community'. The concept relates to flexible citizenship, global/complex citizenship, and cultural citizenship when legal citizenship becomes insufficient in describing the situations in the context of a globalized world and increasing mobilization of people across national borders. Some studies on international students acquiring higher education overseas employ this concept.
} 
response is different from the passive attitude of their former generations. These post-80s native activists negotiate with their peer group, the vulnerable, social organizations, and the structures of authority. Active engagement nurtures a participant culture; the processes reinforce each other. ${ }^{8}$ The following figure summarizes the above argument on citizenship types and the explanation of migration status and political culture (Table 1).

\begin{tabular}{llll}
\hline $\begin{array}{c}\text { Citizenship } \\
\text { Type }\end{array}$ & \multicolumn{1}{c}{$\begin{array}{c}\text { Born in and growing up } \\
\text { time span }\end{array}$} & \multicolumn{1}{c}{ Migration } & $\begin{array}{c}\text { Political } \\
\text { culture }\end{array}$ \\
\hline Transient & $\begin{array}{l}\text { End of WWII to end of } \\
\text { touch base immigration } \\
\text { policy }\end{array}$ & $\begin{array}{l}\text { Refugees, migrants, sojourners } \\
\text { from China }\end{array}$ & Parochial \\
\hline Hidden & $1960 \mathrm{~s}-1970 \mathrm{~s}$ & $\begin{array}{l}\text { Native born, emigrant to Western } \\
\text { countrics, cxpatriates in China }\end{array}$ & Subject \\
\hline Active & $\begin{array}{l}\text { 1980s and beyond } \\
\text { (generally known as post- }\end{array}$ & Native born & Participate \\
& $80 \mathrm{~s}$, post-90s) & & \\
\hline
\end{tabular}

Table 1. Typology of Citizenship, Migration and Political Culture

Source: the author

\section{The Anti-Express Railway Campaign}

\section{Demolition of Star Ferry and Queen's Pier}

It is worth mentioning several pioneer campaigns to illustrate activism by the youth of this generation. These can be regarded as the origin of native movements when the ad hoc organization adopted the name 'Local Action'. The model of transgressive movements gradually emerged. These youth participants employed direct actions, including the occupation of piers, blocking demolition workers and chaining themselves up in resistance to the police removing them. The actions were basically peaceful, in a passive manner with minor bodily contact with the police, such as swarming.

These actions share a common theme of heritage and conservancy. The most wellknown campaigns are against the demolition of Edinburgh Place Ferry Pier (Star Ferry Pier) in 2006 and Queen's Pier in 2007. Both piers were located in Edinburgh Place, the waterfront of Central on Hong Kong Island. The clock tower of Star Ferry was the landmark of Central since being erected in the 1950s. Queen's Pier was listed as a 'Grade 1 Historical Building' by the Antiquities Advisory Board of Hong Kong. These structures are part of the collective memory of Hongkongers.

The development was for reclamation and construction of roads to ease the congestion in Central, the central business district of Hong Kong. The theme of the campaigns concerns culture and heritage. But the opposition was also linked to wider social and political causes. The spirit of 'anti-Central values' arose first, representing opposition to distorted development, top-down urban planning, nepotism favouring giant developers and an undemocratic political system ${ }^{9}$.

\footnotetext{
${ }^{8}$ The timing is relevant because Britain and China had reached the agreement in 1984 in determining the handover of Hong Kong under the rule of China in 1997.

${ }^{9}$ The 'Central' here refers to the central government of China in Beijing.
} 


\section{Sino-Hong Kong Express Railway Project}

The Sino-Hong Kong Express Railway Project related to this study is, to be exact, the construction of the Hong Kong section of the 'Guangzhou-Shenzhen-Hong Kong Express Rail'. (Figure 2) This involved the selection of the railway terminus which was planned to be on reclaimed land on the western side of the Kowloon peninsula, next to the central business district of Hong Kong. An alternative was suggested for construction in Kam Sheung Road of the New Territories near the border with China as proposed later on, by the nongovernmental think tank, Professional Commons.

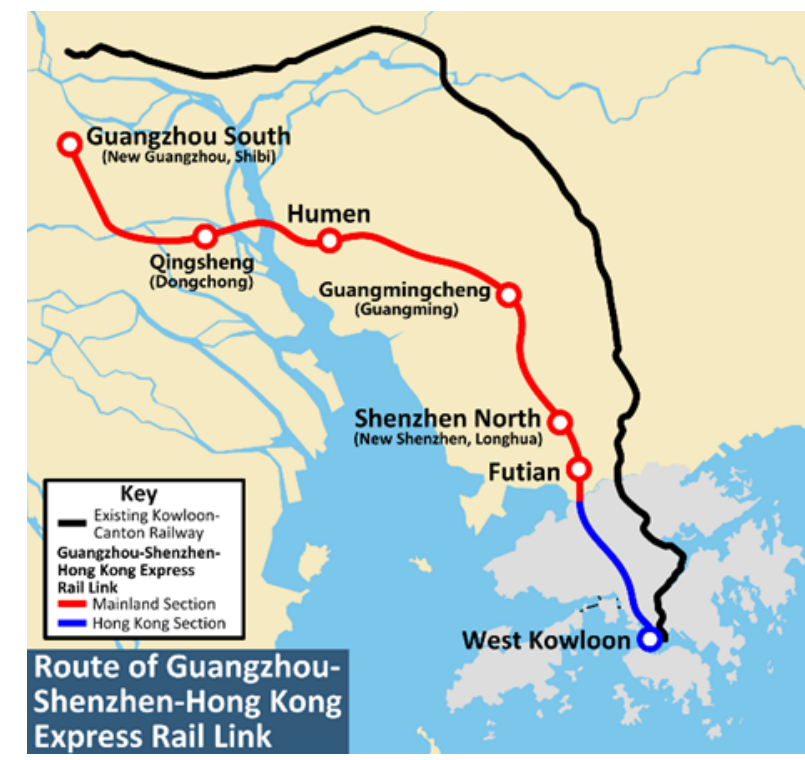

\section{Figure 2. Route Map of Sino-Hong Kong Express Rail Link}

Source: Guangzhou-Shenzhen-Hong Kong Express Rail Link (c) Altt311

(https://upload.wikimedia.org/wikipedia/commons/9/94/Guangzhou_Shenzhen_Hongkong_Express_Rail_Link_ en.svg ), GNU FDL

The railway will link Hong Kong closer to China, with a journey time from Kowloon terminus to Shenzhen, the border city of China for only 14 minutes. Most importantly, it incorporates Hong Kong into the national-wide construction of a high-speed railway network in China. The project will bring about employment opportunities for both Mainland China and Hong Kong, especially after the global financial crisis in 2008. When the railway comes into operation, the improvement in transportation will promote the economic integration of Hong Kong into the Pan Pearl River Delta region of southern China.

However, the high-speed railway project itself is controversial in both Hong Kong and China. The length of the Hong Kong section is only $26 \mathrm{~km}$, but the construction costs are up to US $\$ 8$ billion (in 2009 prices), which has been cited as being the most expensive railway per kilometre in the world. Even this budget was believed to be underestimated ${ }^{10}$. The location of the terminus and land resumption cost along its route have inflated the cost

\footnotetext{
${ }^{10}$ The Hong Kong Government applied again to the Legislative Council additional budget for the project in 2015. HK\$20 billion (US\$2.56 billion) is requested to top-up making the budget of the whole railway project reach HK\$85 billion (US\$10.9 billion) (Lo 2015).
} 
considerably. However, the maximum operating speed of this short section can only reach $200 \mathrm{~km} / \mathrm{h}$. This poor speed makes it only marginally regarded as a high-speed railway ${ }^{11}$.

The rapid expansion of high-speed railways in China has put the Railway Ministry in debt. Its affordability by the majority of peasant workers is doubtful. The train production, quality of electronic control system and human factors in operations are worrying, as a fatal accident happened in Wenzhou City in China in 2011. A high-speed train collided into another head-on, killing 40 people. The Railway Minister stepped down the following year and was eventually found guilty of corruption for taking advantage of his numerous railway projects $^{12}$.

\section{The Resistance of Tsoi Yuen Village}

The plan to demolish Tsoi Yuen Village, a small village on the railway route triggered the campaign ${ }^{13}$. Tsoi Yuen Village is located in the middle of the New Territories, Hong Kong. The railway development of Hong Kong had been concentrated on the eastern coast ${ }^{14}$ and western plain $^{15}$, leaving the mountainous central area outside the range of urbanization. The neighbourhood comprised 150 households, scattered over an area of about 27 hectares. With a few exceptions, almost all the houses were unlicensed cottages, unauthorized to be erected on farmland. According to the existing cottage policy, these residents are neither entitled to any land nor tenure rights. In the case of public land resumption, no compensation is possible, but ex gratia allowances for moving home will be considered on a case-by-case basis (Legislative Council Secretariat 2000). The villagers were not eligible to be allocated public rental housing flats. In the case of indigenous inhabitants of the New Territories, upon clearance residents are entitled to land for rebuilding their houses. But Tsoi Yuen Village was not an indigenous village.

In 2007, the Mass Transit Railway of Hong Kong adopted an initial plan to build a section of high-speed railway in Hong Kong connecting with Shenzhen City in Mainland China. As the route of this planned railway would pass through Tsoi Yuen Village, the Hong Kong Government announced the clearance of the structures and resumption of public land to be effective in October of 2010.

\section{Prostrating Walk}

The most impressive image of the performance in the protests against Sino-Hong Kong Express Railway Project was the 'prostrating walk' ${ }^{16}$. The term 'prostrating' simply means kneeling down and worshipping by bowing. The word in Chinese carries the meaning of 'bitter' or 'bear the bitter burden'. Prostrating walk is common in Buddhist practice. The most prominent example of prostrating walk is by Tibetan pilgrims. They travel a very long

\footnotetext{
${ }^{11}$ Data are drawn from the Express Rail Link website of its parent company Mass Transit Railway Corporation of Hong Kong.

${ }^{12}$ Information is drawn from the report of the Guardian and the Independent.

${ }^{13}$ Tsoi Yuen village is also known as Tsoi Yuen Tsuen or Choi Yuen Chuen.

${ }^{14}$ Kowloon and Canton Railway Line, in the East along the coastal area of Tolo Harbour, was developed at the beginning of the last century.

${ }^{15}$ Western Railway Line and Light Railway, in the West on the plain of Yuen Long, was developed by the end of the last century.

${ }^{16}$ Different English translation terms for the procession are used, such as 'bitter walk or kuxing' (Fong 2011), 'penance walkers' (Lam and IP 2011), and 'prostrating walk’ (Ma 2012).
} 
way from their home to worship in the Potala Palace, in Lhasa. On their way, the Tibetan Buddhists kneel down every few steps and bow until their hands, head and finally their whole body touches the ground. The performance is repeated and repeated, making the whole journey much longer than if just walking on foot. This is to demonstrate their devotion and willingness to bear the bitterness of a long walk toward the holy land.

However, the immediate idea for the post-1980s prostrating walk came from the antiWTO protest in Hong Kong in 2005. The experienced Korean peasant petitioners did not show their hardline protesting method to Hong Kong but also performed 'Three Steps, One Bow' (pronounced as 'Sambo Ilbae' in Korean) (Hadl, 2005) ${ }^{17}$, - kneeling down and bowing every five steps along the main streets of Hong Kong Island. The alternative hard and soft tactics attracted the media and drew the sympathy of local Hongkongers. This new matching style eradicated the violent image of the clash between South Korean farmers and Hong Kong Police as well as gaining sympathy among the general public of Hong Kong (Sheoin and Yeates, 2009; Kim, 2011). Some of the youth activists participated in the anti-WTO protest. They modified the actions of the Korean peasants and designed their own prostrating walk. Once again, it impressed many people in Hong Kong and drew large numbers of like-minded young people to turn out. The protest performance appeared in several large-scale campaigns repeatedly, even up to the Umbrella Movement - Occupy Central in 2004.

When the budget for the construction of the Express Railway was submitted for approval by the Legislative Council of Hong Kong in December 2009, youth activists called for a siege of the Council. The protestors clashed with the police on some occasions when the pro-establishment legislators left the Council at night after a whole day's session. Most of the time, the rally proceeded peacefully. There were art and music performances outside the Council. They called it a 'resistance carnival' (Fong 2011). In one impressive scene, the youth activists demonstrated their prostrating walk surrounding the Council.

Several pictures of prostrating walk were retrieved from the internet. The images shown are as follows. A small team of demonstrators walked very slowly in single file. The first person held a small vertical banner with a few words showing the theme of the procession, such as 'Against the Express Railway’ or 'Prostrating Walk against the Express Railway' or 'Prostrating walk by university and college students'. A few demonstrators wore clothes with the same written message. Some of the demonstrators walked in bare feet. (Figure 3 \& 4)

\footnotetext{
${ }^{17}$ The 'Three Steps, One Bow' style, is known as 'Sambo Ilbae' in both Korean and Mandarin Chinese. The matching style consists of walking three steps forward, prostrating, rising, and then repeat the steps again and again. There is a tradition for Korean Buddhist monks and nuns to walk in this way so as to 'shed the three poisons - greed, anger and delusion' (Hadl, 2005). The performance also spread to Thailand during the protest against Thai-US Free Trade Agreement (Kim, 2011).
} 


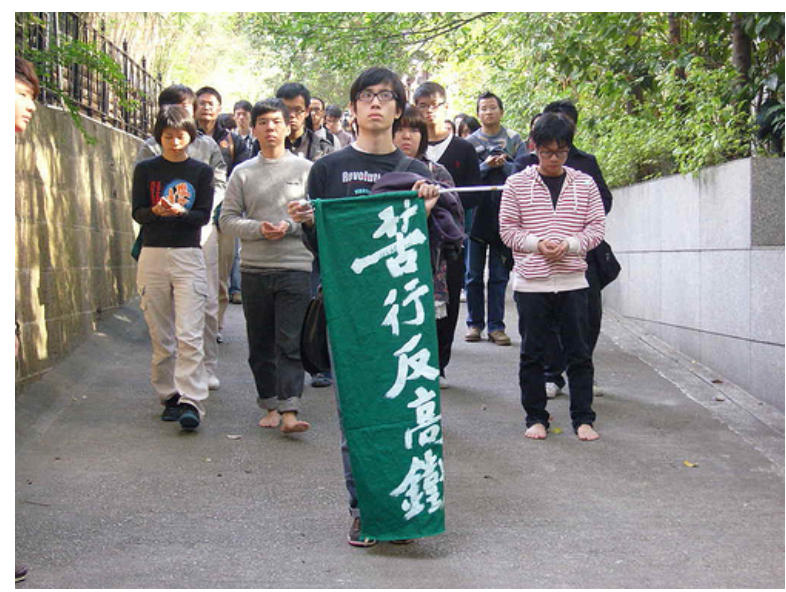

Figure 3. The first person held a small vertical banner

Source: Anti-Express Railway and the Grassroots: A discussion with Chu Hoi-dick (c) inmediahk (https://www.flickr.com/photos/47024905@N08/4499903170/), CC BY-NC 2.0

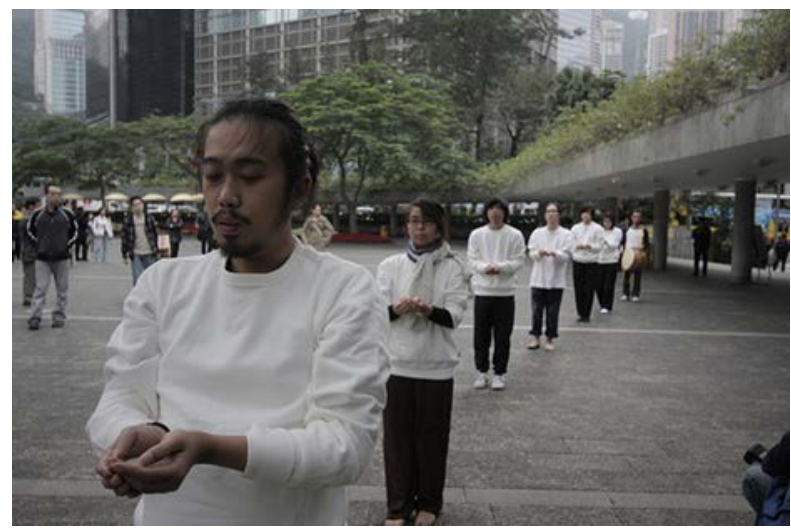

Figure 4. Demonstrators in Single File

Source: Express Railway Campaign Newsletter (Chinese Edition) (Inmediahk, n.d.)

The whole team walked at a very slow pace. Every 26 steps, they knelt down together. Then they stood up and walked for another cycle repeatedly. The 26-step cycle represented the length of the Express Railway in Hong Kong. Each time they knelt down until their hands and forearms touched the ground. They put some rice in their palms, representing a reconstruction of the relationship between humans, land and agriculture. (Figure 5)

A drummer followed the team at the back. He hit a Korean drum infrequently at almost one-minute intervals. The beat guided the pace of the procession. Demonstrators kept silent all the way with no talking or shouting of any slogans. They all had serious expressions on their faces. The only sound was the drum beat. The low tone, deep sound and slow rhythm of the drum beat produced a solemn atmosphere, making the procession akin to a religious ritual. 


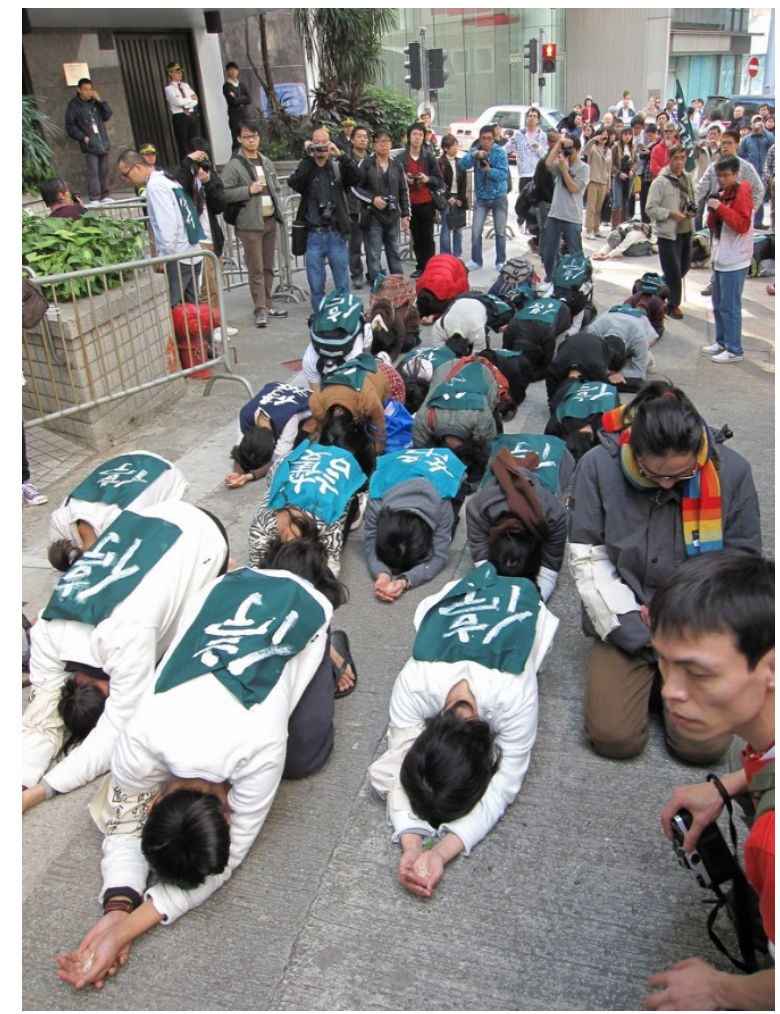

Figure 5. 26-Step Cycle and Kneeling Down

Source: Anti-Guangzhou-Shenzhen-Hong Kong rail oppositions Jan 2010 protest (c)HKFotopoint (https://upload.wikimedia.org/wikipedia/commons/6/6e/Promotion_activity_of_HK 80_Night_AntiExpress_Rail_Link_01.jpg), CC-SA-3.0.

After the success of the first prostrating walk, appearing in front of the Legislative Council during the budget which won a significant amount of sympathy (Fong 2011; Lam \& Ip 2011; Ma 2012), there were several more rounds of prostrating walk. One reached all five regions of Hong Kong, greatly assisting the movement. Another visited a university campus to recruit more students to participate in the later actions of the movement.

\section{Discussion}

Rituals are seldom employed in protests in Hong Kong. Prostrating walk is a Buddhist ritual which can be easily understood by Hongkongers. The post-80s activists adopted the ritual for the campaign against the Express Railway, because some of them had joined the anti-WTO protest the year before and had been impressed by the Korean farmers' 'Three Steps, One Bow'. Also, the general public and mass media seemed quite attracted to the Korean farmers' ritual. As such, the activists designed the rules and performance and assigned meanings relevant to the campaign's theme against the Express Railway.

The communication effects of prostrating walk are three-fold: mass media, the internet and direct contact. First of all, it won back coverage of the mass media. The unique image and features of the protest performance attracted TV cameras and newspaper photographers. The message was able to reach the general public. Before that, mainstream media turned a cold shoulder to the voice of villagers from Tsoi Yuen Village and there had been little coverage of the campaign against the Express Railway. 
Most importantly, images of the prostrating walk were captured by many mobile phones and digital cameras. These were shared among social networking websites: Facebook, online photo albums and blogs. Although WhatsApp and Lines over mobile networks had not yet been introduced in 2009, other instant message services over the internet, including Windows Live Messenger which consisting photo sharing capability was very popular among youths. The information and especially, the images of the prostrating walk were able to be disseminated widely to some sectors of society.

Finally, the youth activists performed prostrating walk directly in all regions of Hong Kong and university campuses. The audiences witnessed the procession as if they were in the actual scene of resistance and protest. The symbolic meaning was that the Express Railway Project was not far away from everyone. The repeat performances transmitted these messages everywhere. Actions spoke louder than words in this situation.

The actions of these youth activists in this campaign distinguished them from their pandemocrat politicians and trade union predecessors ${ }^{18}$. The dual tactics of transgressive direct action and the prostrating walk were new to the public and participants. This was also learnt from the Korean peasant protester during the WTO summit in Hong Kong. Besides, the calm and peaceful prostrating walk, another transgressive mode of actions was also employed though with lesser frequency. The latter consisted of refusing to stay in the designated protest areas, storming the police lines, blockage of entrances to the Legislative Council building, and the like. They had entered a new era of social movements in Hong Kong which was not the same as those campaigns organized previously by political parties and trade unions. The new identity provided supporters with fresh feelings, new hope and expectations. The activists set up ad hoc, single issues and an informal organization to mobilize the movement. They recruited participants via the internet and at the scene. The demarcations between members and non-members, leaders and participants were blurred. Roadside audiences were able to take part and quit at any time. At the least, taking a picture and sharing it on Facebook, a blog, and other internet websites is a kind of participation in the movement. The 'online discursive community' and 'affection mobilization' over the internet facilitated the dialogue, participation and agenda setting (Lam \& Ip n. d.; Ma 2012). The label, 'post1980s', in fact, was applied by mainstream media to these youth activists. The participants of the various campaigns in 2009 and 2010 consisted of a wide age group, as well as the middle to old aged villagers. There were also meetings and discussions at the scene. Topics ranged from decisions on next steps to be taken or whether to break through the police lines or not, to more conceptual meanings of the campaign. A participatory and deliberative type of movement replaced the top-down, representative type of action organized by pan-democrat political parties and trade unions ${ }^{19}$. The internal mode of action of the youth activists demonstrated the vertical (between leader and participants) and horizontal (between members and non-members) de-differentiation pinpointed by Offe (1985, p.829) regarding new social movements.

The de-differentiation mentioned above shortened the social distance between activists and the masses. An 'us' feeling emerged, no matter whether the participants were in their 20s

\footnotetext{
${ }^{18}$ The pan-democracy camp refers to the Democratic Party and their alliance in Hong Kong which demands for democracy, including the universal suffrage of the Chief Executive and the Legislative Council.

19 The Democratic Party is well-known for its 'big brother' (top-down) culture.
} 
or not. They shared a common identity of this post-1980s youth activists or 'us'. Many turned out on 18 December 2009 to form a large crowd to besiege the Legislative Council of Hong Kong (12.18 Besiege of Legco Action) to demonstrate against the budget for construction of the Express Railway. The prostrating walk first appeared on that day and became an icon for students and youth activists, and one step forward, the symbol of the campaign. The prostrating walk further spread to all five regions of Hong Kong and university campuses in the next year to strengthen and widen this collective identity. There is no doubt that it played the role of 'a symbolic resource as a signifier of collective identity' of post-1980s youth activists (Fominaya 2010, p.396).

The Sino-Hong Kong Express Railway signified the fusion of the economies of Mainland China and Hong Kong. A pro-establishment legislator even pushed it into the political sphere by claiming that the Express Railway was the demonstration of China's sovereignty in post-colonial Hong Kong. The application of 'main cultural patterns' (Touraine 1985) or legitimate identity (Castells 2004) toward Hong Kong had stirred up the opposition to the railway. In fact, the collective identity of Hongkongers was slowly and gradually built up during the post WWII development of the British colony of Hong Kong. After the the 1997 handover, the Hongkonger identity formation is switched to an accelerating pace. Doubtlessly, the formation of the Hong Kong identity stems from "economic achievements, cultural sophistication and democratic values" which demonstrates a "superiority over or difference from China” (Kaeding 2011, p.16).

The previously mentioned 'typology of citizenship, migration and political culture' provides the basis for the claim of nativism. Those native born in the 1980s and beyond are active citizens of Hong Kong. They adopted a native identity together with the culture, lifestyle and freedom in a natural way. In addition, the collective memory of historical events helps to internalize the negative connotations associated with communist China, and the Chinese identity imposed, to name a few, the 1989 Beijing Tiananmen massacre, the establishment of the provisional legislature ${ }^{20}$ in 1997 and the attempt to introduce the Treason Law in $2003^{21}$. The latter triggered the largest-scale demonstration in the history of Hong Kong. More than half a million people turned out on the street, which led to the government dropping the proposed ordinance. Campaigns for the conservation of the Star Ferry and Queen's Pier in 2006-07 described in the early part of this paper aimed to protect the cultural heritage of Hong Kong. These historical structures were symbols signifying Hong Kong's value and lifestyle. Their demolition implied a 'hegemony of the development ethos' and the vested interests in existing institutions,

[i]n which economic or infrastructure development was perceived as having overriding priority over other values or considerations... Lopsided governance system in which developers' interests were protected by the functional constituencies and the vested interests in the Election Committee (Cheung 2014, p.437).

\footnotetext{
${ }^{20}$ Beijing abolished all popularly elected Councils of colonial Hong Kong immediately after the 1997 handover and appointed Provisional Legislature and subordinate councils. It was known as destroying the 'through train' (of political institutions) after China's resumption of its sovereignty over Hong Kong. The last Governor of British Hong Kong opened up more seats for universal suffrage at all levels, which angered China.

${ }^{21}$ According to Article 23 of the Basic Law (mini-constitution of Hong Kong), the Hong Kong Special Administrative Region 'shall enact laws on its own to prohibit any act of treason'.
} 
Similarly, the resistance of Tsoi Yuen Village and campaign against the Express Railway in 2009-10 'called for rediscovering Hong Kong's identity and rethinking how people are linked to land' (Yew and Kwong 2014, p.1099). Although new social movements in Western countries are characterized by less concern with state-level or governmental politics, the post80's campaign against Express Railway inevitably challenged local political relations and Beijing-Hongkong relations implicitly and indirectly. After all, Touraine's (1981) claim about the decline of state influence in everyday life is not borne out in Hong Kong, where there has been increased political and social control by China since the 1997 handover. The following figure illustrates the concept of various changes in post-colonial Hong Kong triggering an adjustment in collective identity which leads to the rise of nativism and youth activism in the perspective of new social movement. (Figure 6)

\begin{tabular}{|c|c|c|}
\hline $\begin{array}{c}\text { Political Changes } \\
\text { From a British colony } \\
\text { to the Hong Kong SAR } \\
\text { of China; } \\
\text { authoritarian replacing } \\
\text { colonialism }\end{array}$ & $\begin{array}{l}\text { Social Changes } \\
\text { From industrialization, } \\
\text { development first, 'central (CBD } \\
\text { or materialistic) value' } \\
\text { to post-materialistic and post- } \\
\text { industrial }\end{array}$ & $\begin{array}{l}\text { Cultural Conflicts } \\
\text { Sinification; } \\
\text { social control of } \\
\text { main cultural } \\
\text { patterns }\end{array}$ \\
\hline \multicolumn{3}{|l|}{5} \\
\hline \multicolumn{3}{|c|}{$\begin{array}{l}\text { Identity Changes: } \\
\text { transients to active citizen of Hong Kong; } \\
\text { Chinese to Hongkongers; } \\
\text { uishing from politicians and trade unionists }\end{array}$} \\
\hline & & \\
\hline $\begin{array}{l}\frac{\text { Nativism }}{\text { De-Sinification; }} \\
\text { against top-down assimilatic } \\
\text { with China; } \\
\text { prevent economic depender } \\
\text { and integration of China }\end{array}$ & $\begin{array}{c}\text { Youth Activism } \\
\text { Prostrating walk; } \\
\text { transgressive direct action; } \\
\text { widely use of internet and } \\
\text { ICT technology for } \\
\text { mobilization }\end{array}$ & $\begin{array}{l}\text { New Social Movement } \\
\text { From class-based to } \\
\text { issue-based; } \\
\text { bottom-up, } \\
\text { participatory \& } \\
\text { deliberative }\end{array}$ \\
\hline
\end{tabular}

Figure 6. Origin and Sustaining Collective Identity and Native Youth Activism

Source: the Author

\section{Conclusion}

Tsui Yuen village was a small agricultural village in Hong Kong, a highly urbanized metropolis. The demolition of the village to pave the way for the construction of an Express Railway used to be a 'normal' development practice. But with the cultural shift towards nonmaterialism during the post-industrial period in Hong Kong, people have rethought the existing 'Central District (CBD) value' and 'economic first' development strategy. New social movements have emerged, replacing old social movements. Campaigns are no longer class-based, but issue-based. The mode of action, social movement organizations, values and actors are not the same. 
The rise of youth activism is a consequence of new social movement emergence. The new collective identity has also contributed to the native social movements in Hong Kong. The momentum has been built up gradually during the early campaigns in relation to the Star Ferry Pier and Queen's Pier in 2006-07. The civic organization of youth activists, 'Local Action' was recognized. But these ad hoc, single issue and informal organizations do not last for long. The de-differentiation of the mode of action implies highly flexible and less clear demarcation between leaders and participants. With the advancement of the internet and communication technology, the youth activist movements are flourishing.

The impressive prostrating walk was a ritual tailor-made for this campaign because of its emotional appeal, which also helped to distinguish the post-80s activists from those organized by pan-democrat politicians. It also signifies the native identity in social movements. Such rituals and approaches had not been seen in the various actions organized by political parties and trade unions before. Nativism serves to explain the Hongkonger identity growing rapidly in response to the top-down assimilation by China. It reactively responds to the rising conflict with the social control of main cultural patterns and attempts to reconstruct a social, cultural and political identity of Hong Kong proactively.

Post-1980s youth activism is not limited to the revolt of a group of radical young people. It is the shift of the values and orientation of a whole generation. They are native born, active citizens of Hong Kong, different from former migrant generations. Their identity and culture can only be reproduced through active participation.

\section{Acknowledgements}

I acknowledge the insights from the anonymous reviewers which have helped me to strengthen this paper.

\section{References}

Almond, G.A. \& Verba, S. 1963, The Civic Culture: political attitude and democracy in five nations, Princeton University Press, Princeton, N.J. doi: https://doi.org/10.1515/9781400874569

Bell, C. 1997, Ritual: Perspectives and Dimensions. Oxford University Press, New York. Castells, M. 2004, The Power of Identity, $2^{\text {nd }}$ edition. Blackwell Publishing, Malden, Oxford. Cheung, C.Y. 2014, 'Hong Kong's systemic crisis of governance and the revolt of the "post80's” youths: The Anti-Express Rail campaign” in Cheng, J.Y.S. (ed), New Trends of Political Participation in Hong Kong, City University of Hong Kong Press, Hong Kong, pp. 417-447.

Cheung, G.C.K. 2007, China Factors: Political Perspectives \& Economic Interactions, Transaction publishers, New Brunswick, N.J.

Diani, M. 2006, 'The concept of social movement' in Lipschutz, R.D. (ed), Civil Societies and Social Movements, Ashgate Publishing, Aldershot, pp.129-153.

Express Railway Campaign Newsletter (Chinese Edition) n.d., Accessed 8 June 2014, http://www.inmediahk.net/node/1005408

Eyerman, R. 2005, 'How social movements move: Emotions and social movements', in Flam, H. \& King, D. (eds), Emotions and Social Movements, Routledge, New York. 
Fowler, E. 2015, 'A borrowed place on borrowed time: Can Hong Kong ever be home?', The Hong Kong Free Press, Accessed 12 December 2016, https://www.hongkongfp.com/2015/09/26/hong-kong-a-borrowed-place-on-borrowed$\underline{\text { time/ }}$

Fominaya, C.F. 2010, 'Collective identity in social movements: Central concepts and debates’, Sociology Compass, vol. 4, no. 6, pp. 393-404. doi: https://doi.org/10.1111/j.1751-9020.2010.00287.x

Fong, Y.K. 2011, 'Tsoi Yuen Resistance and Post-80s Generation: A new wave of domestic social movement', Master's Thesis, University of Helsinki, Accessed 2 March 2015, https://helda.helsinki.fi/bitstream/handle/10138/26606/thesis_YKF\%202011.pdf?seque nce

Friedmann, J. 2002, The Prospect of Cities. Minneapolis, University of Minnesota Press. Guangzhou-Shenzhen-Hong Kong Express Rail Link n.d., Accessed 2 March 2015, https://en.wikipedia.org/wiki/Guangzhou\%E2\%80\%93Shenzhen\%E2\%80\%93Hong_K ong_Express_Rail_Link

Hadl, G. 2005, 'Korean protest culture', Kyoto Journal, vol. 60, Accessed 28December 2016, http://www.kyotojournal.org/the-journal/society/korean-protest-culture/

Hurd, M. 2014, 'Introduction - Social movements: Ritual, space and media', Culture Unbound, vol. 6, pp. 287-303. doi: https://doi.org/10.3384/cu.2000.1525.146287

Goodwin, J. and Jasper, J.M. 2006, 'Emotions and social movements', in Stets, J.E. and Turner, J.H. (eds), Handbook of the Sociology of Emotions, Springer US, pp. 611-635. doi: https://doi.org/10.1007/978-0-387-30715-2

Jones, M., Jones, R. and Woods, M. 2004, An Introduction to Political Geography: Space, Place and Politics, Routledge, London.

Matthews G., Ma, K.W.E. \& Lui, T.L. 2007, Hong Kong, China: Learning to Belong to a Nation, Routledge, New York.

Kaeding, M.P. 2011, 'Identity formation in Taiwan and Hong Kong- How much difference, how many similarities?' in Schubert, G and Damm, J. (eds), Taiwanese Identity in the 21th Century: Domestic, Regional and Global Perspectives, Routledge, London, pp. 258-279.

Kim, A.S. 2011, 'Left out: People’s solidarity for social progress and the evolution of Minjung after authoritarianism', in Shin G.W and Chang, P.Y. (eds.), South Korean Social Movements: From Democracy to Civil Society. Routledge, Abingdon, pp. 245269.

Lam, O.W. and Ip, I.C., 2011, Hong Kong: A New Page for Affective Mobilization', in Ip, I.C (ed.) Social Media Uprising in the Chinese-speaking world, Hong Kong In-Media, Hong Kong.

Legislative Council Secretariat (2000). Report of the Panel on Housing on Cottage Area Clearance: Paper for the House Committee meeting on 9 June 2000, Accessed 2 March 2015, http://www.legco.gov.hk/yr99-00/english/hc/papers/cb1-1790.pdf

Lo, A. 2015, MTR and gov't pass the buck as XL rail late and over-budget. Hong Kong Free Press [online] 3 July, Accessed 6 May 2016, https://www.hongkongfp.com/2015/07/03/mtr-and-government-pass-the-buck-overhigh-speed-delays-and-budget-overrun/ 
Ma, L.Y.M. 2012, 'Framing processes and social media: A frame analysis of the Tsoi Yuen Resistance Movement', Paper presented at the 65th World Association of Public Opinion Research Annual Conference, 14-16 June, University of Hong Kong, Hong Kong.

Ma, N. 2009, 'Social movements and state-society relationship in Hong Kong' in KuahPearce, K.E. and Guiheux, G. (eds), Social Movements in China and Hong Kong: The Expansion of Protest Space, Amsterdam University Press, Amsterdam, pp. 45-63. doi: https://doi.org/10.5117/9789089641311

Mac Sheoin, T. and Yeates, N. 2009, 'Policing anti-globalization protests: Patterns and variations in state response', in Dasgupta, S and Nederveen, J (eds), Politics of Globalization, Sage, New Delhi, pp. 197-241. doi: https://doi.org/10.4135/9788132108283.n10

McAdam, D. \& Snow, D. 1997, 'Social Movements: Conceptual and Theoretical Issues' in MacAdam, D. and Snow, D. (eds), Readings on Social Movements, Roxbury Publishing, Los Angeles, pp. xviii-xxvi.

Marston, S.A. and Mitchell, K. 2004, 'Citizens and the State: Citizenship Formations in Space and Time', in Barnett, O, and Low, M. (eds), Spaces of Democracy: Geographical Perspectives on Citizenship, Participation and Representation. SAGE, Thousand Oaks, pp.93-112. doi: https://doi.org/10.4135/9781446216309.n5

Melucci, A. 1985, 'The symbolic challenge of contemporary movements', Social Research, vol. 52, no. 4, pp. 789-816.

Melucci, 1996, Challenging Codes: Collective Action in the Information Age. Cambridge University Press, Cambridge.

Miraftab, F. and Wills, S, 2005, 'Insurgency and spaces of active citizenship: The story of Western Cape Anti-eviction campaign in South Africa', Journal of Planning Education and Research, vol 25, pp. 200-217. doi: https://doi.org/10.1177/0739456X05282182

Offe, C. 1985, 'New social movements: Challenging the boundaries of institutional politics' Social Research, vol. 52, no. 4, pp. 818-868.

Or, N. H.K. \& Lau, C. H.M. 2014, 'The rise of transgressive contention by young activists: The recent cases in Hong Kong', Journal of Youth Studies, vol. 17, no.1, pp. 57-77.

Polletta, F. \& Jasper, J.M. 2001, 'Collective Identity and Social Movements', Annual Review of Sociology, vol. 27, pp. 283-305. doi: https://doi.org/10.1146/annurev.soc.27.1.283

Prostrating Walk in Five Regions (Chinese edition) n.d, Accessed 3 March 2015, https://zh.wikipedia.org/wiki/\%E4\%BA\%94\%E5\%8D\%80\%E8\%8B\%A6\%E8\%A1\%8 $\underline{\mathrm{C}}$

Public Opinion Programme, The University of Hong Kong 2014, HKU POP releases latest survey on Hong Kong people's ethnic identity. [press release] 17 June 2014. Accessed 4 March 2015, http://hkupop.hku.hk/english/release/release1150.html

Public Opinion Programme, The University of Hong Kong n.d, Table: People's Ethnic Identity Survey. [online] Accessed March 15, 2016, https://www.hkupop.hku.hk/english/popexpress/ethnic/eidentity/poll/datatables.html

Rose, F. 1997, 'Towards a class-cultural theory of social movements: Reinterpreting new social movements', Sociological Forum, vol. 12, no. 3, pp. 461-494. doi: https://doi.org/10.1023/A:1024681328657 
Rose, N. 2000, 'Governing cities, governing citizens', in Democracy, citizenship and the global city, Engin F.I. (ed), Routledge, London, pp.95-109.

Routledge, P. 1997, 'The imagineering of resistance: Pollok Free State and the practice of postmodern politics', Transactions of the Institute of British Geographers, vol.22, no. 3, pp. 359-376. doi: https://doi.org/10.1111/j.0020-2754.1997.00359.x

Skeiker, F.F. 2010, 'Performing liminal citizenship: using applied theatre techniques to civically engage international students', Journal of Applied Research in Higher Education, vol 2, no. 2, pp. 11-19. doi: https://doi.org/10.1108/17581184201000010

Staricco, J.I. 2012, 'The French May and the roots of postmodern politics', Rassegna Italiana di Sociologia, vol. 2012, no. 3, pp. 447-472, DOI: 10.1423/38248.

Tajfel, H. \& Turner, J.C. 1979, 'An integrative theory of intergroup conflict', in Austin W.G. and Worchel, S. (eds), The Social Psychology of Intergroup Relations, Brooks-Cole, Monterey, CA, pp.33-47.

Taylor, G. 2010, The New Political Sociology: Power, Ideology and Identity in an Age of Complexity, Palgrave Macmillan, Basingstoke, UK, doi: https://doi.org/10.1057/9780230276062

Teske, N. 1997, Political Activists in America: The Identity Construction Model of Political Participation, Cambridge University Press, Cambridge.

Tilly, C. 2004, Social Movements, 1768-2004, Paradigm Publishers, Boulder, CO.

Touraine, A. 1985, 'An introduction to the study of social movements', Social Research, vol. 52, no. 4, pp. 749-787.

Transport and Housing Bureau 2009, Items for Public Work Subcommittee of Financial Committee-Special ex-gratia payments in relation to the Hong Kong section of the Guangzhou-Shenzhen-Hong Kong Express Rail link, Accessed 8 March 2015, http://www.legco.gov.hk/yr09-10/english/fc/pwsc/papers/p09-72e.pdf

Tsui, H. 2007, The Demolition of Star Ferry Pier: Urban reclamation versus cultural heritage in Hong Kong. Accessed 6 May 2015, http://www.eurozine.com/the-demolition-of-starferry-pier/

Yew, C.P. \& Kwong, K.M. 2014, 'Hong Kong identity on the rise', Asian Survey, vol. 54, no. 6, pp. 1088-1112. doi: https://doi.org/10.1525/as.2014.54.6.1088 